\title{
Sources and sinks of formic, acetic, and pyruvic acids over central Amazonia: 2. Wet season
}

\section{Citation}

Talbot, R. W., M. O. Andreae, H. Berresheim, D. J. Jacob, and K. M. Beecher. 1990. "Sources and Sinks of Formic, Acetic, and Pyruvic Acids over Central Amazonia: 2. Wet Season." Journal of Geophysical Research 95 (D10): 16799. doi:10.1029/jd095id10p16799.

\section{Published Version}

doi:10.1029/JD095iD10p16799

\section{Permanent link}

http://nrs.harvard.edu/urn-3:HUL.InstRepos:14121835

\section{Terms of Use}

This article was downloaded from Harvard University's DASH repository, and is made available under the terms and conditions applicable to Other Posted Material, as set forth at http:// nrs.harvard.edu/urn-3:HUL.InstRepos:dash.current.terms-of-use\#LAA

\section{Share Your Story}

The Harvard community has made this article openly available.

Please share how this access benefits you. Submit a story.

\section{Accessibility}




\title{
Sources and Sinks of Formic, Acetic, and Pyruvic Acids Over Central Amazonia 2. Wet Season
}

\author{
R. W. Talbot, ${ }^{1,2}$ M. O. Andreae, ${ }^{3,4}$ H. Berresheim, ${ }^{3,5}$ D. J. Jacob ${ }^{6}{ }^{\text {AND K. M. Beecher }}{ }^{1}$
}

We have determined the gas' phase concentrations of formic $(\mathrm{HCOOH})$, acetic $\left(\mathrm{CH}_{3} \mathrm{COOH}\right)$, and pyruvic $\left(\mathrm{CH}_{3} \mathrm{C}(\mathrm{O}) \mathrm{COOH}\right)$ acids in the forest canopy, boundary layer, and free troposphere over the central Amazon Basin during the April-May segment of the 1987 wet season. At 150 -m altitude in the boundary layer the daytime average concentrations were $430 \pm 225,340 \pm 155$, and $25 \pm 15 \mathrm{ppt}$ for $\mathrm{HCOOH}, \mathrm{CH}_{3} \mathrm{COOH}$, and $\mathrm{CH}_{3} \mathrm{C}(\mathrm{O}) \mathrm{COOH}$, respectively. These values were fivefold lower than those observed in the 1985 dry season. Concentrations measured near canopy top were not significantly different from boundary layer values $(P=0.10)$, while concentrations in the lower canopy were significantly less. Concentrations in the free troposphere $(5 \mathrm{~km})$ were lower than in the boundary layer and averaged $170 \pm 40,210 \pm 40$, and $15 \pm 15$ ppt for $\mathrm{HCOOH}, \mathrm{CH}_{3} \mathrm{COOH}$, and $\mathrm{CH}_{3} \mathrm{C}(\mathrm{O}) \mathrm{COOH}$, respectively. Fivefold enhancements of $\mathrm{CH}_{3} \mathrm{C}(\mathrm{O}) \mathrm{COOH}$ concentrations were observed in convective outflows at 5- to $6-\mathrm{km}$ altitudes. Aerosol carboxylate concentrations were usually below our detection limit of 5-10 ppt. Preliminary branch enclosure measurements indicated significant direct emission of carboxylic acids by vegetation. A one-dimensional photochemical model for the canopy and the boundary layer was used to examine the contributions from various sources to the carboxylic acid budgets. Model results indicate that direct emissions from vegetation can account for most of the concentrations observed in the canopy. These emissions peak during the daytime hours, and 24-hour average upward fluxes at canopy top are $4.4 \times 10^{9}, 3.7 \times 10^{9}$, and $2.8 \times 10^{8}$ molecules $\mathrm{cm}^{-2} \mathrm{~s}^{-1}$ for $\mathrm{HCOOH}, \mathrm{CH}_{3} \mathrm{COOH}$, and $\mathrm{CH}_{3} \mathrm{C}(\mathrm{O}) \mathrm{COOH}$, respectively. However, direct emissions from vegetation can account for only a small fraction of the observed carboxylic acid concentrations in the boundary layer, suggesting a large contribution from atmospheric sources. The atmospheric reactions previously suggested in the literature as sources of carboxylic acids (gas phase decomposition of isoprene, $\mathrm{CH}_{3} \mathrm{CO}_{3}+$ peroxy, aqueous phase oxidation of $\mathrm{CH}_{2} \mathrm{O}$ ) appear to be too slow to explain the observed concentrations. Other atmospheric reactions, so far unidentified, could make a major contribution to the carboxylic acid budgets.

\section{INTRODUCTION}

Precipitation acidity in remote regions of the world is typically dominated by $\mathrm{HCOOH}$ and $\mathrm{CH}_{3} \mathrm{COOH}$ [Galloway et al., 1982; Keene and Galloway, 1986]. Our measurements in central Amazonia, Brazil, during the 1985 dry season showed that these carboxylic acids were the principal contributors to rainwater acidity in that region [Andreae et al., $1988 a]$. Gas phase concentrations measured at canopy top averaged $1.6 \pm 0.6$ and $2.2 \pm 1.0$ parts per billion by volume (ppb) for $\mathrm{HCOOH}$ and $\mathrm{CH}_{3} \mathrm{COOH}$, respectively [Andreae et al., 1988a]. Concentrations of carboxylates in the atmospheric aerosol were about 2 orders of magnitude lower. The highest concentrations of aerosol $\mathrm{HCOO}^{-}$and $\mathrm{CH}_{3} \mathrm{COO}^{-}$ were associated with haze layers originating from biomass burning [Andreae et al., 1988b].

Keene and Galloway [1986] hypothesized that primary and

\footnotetext{
${ }^{1}$ Atmospheric Sciences Division, NASA Langley Research Center, Hampton, Virginia.

${ }^{2}$ Now at Institute for the Study of Earth, Oceans and Space, University of New Hampshire, Durham.

${ }^{3}$ Department of Oceanography, Florida State University, Tallahassee.

${ }^{4}$ Now at Max-Planck-Institute for Chemistry, Mainz, Federal Republic of Germany.

${ }^{5}$ Now at School of Geophysical Sciences, Georgia Institute of Technology, Atlanta.

${ }^{6}$ Earth and Planetary Sciences, Division of Applied Science, Harvard University, Cambridge, Massachusetts.
}

Copyright 1990 by the American Geophysical Union.

Paper number 90JD00097.

0148-0227/90/90JD-00097\$05.00 secondary emissions from vegetation are responsible for the enhanced rainwater concentrations of $\mathrm{HCOOH}$ and $\mathrm{CH}_{3} \mathrm{COOH}$ observed over continents during the growing season. The strong seasonality of these species in the gas phase observed at a temperate site in eastern Virginia supports their hypothesis [Talbot et al., 1988]. Other sources of carboxylic acids include biomass burning [Talbot et al., 1988] (also, G. Helas et al., Measurements of organic acids in equatorial Africa during DECAFE 88, submitted to Journal of Geophysical Research, 1989; hereinafter referred to as submitted 1989) and possibly emissions from formicine ants [Graedel and Eisner, 1988]. Jacob and Wofsy [1988b] suggested that the oxidation of isoprene could provide a significant source of formic, methacrylic, and pyruvic acids over vegetated regions. Acetic acid is produced in the atmosphere by reactions of $\mathrm{CH}_{3} \mathrm{CO}_{3}$ with $\mathrm{HO}_{2}$ and $\mathrm{CH}_{3} \mathrm{O}_{2}$ [Moortgat et al., 1989a, b], where $\mathrm{CH}_{3} \mathrm{CO}_{3}$. can be supplied by atmospheric oxidation of biogenic hydrocarbons or decomposition of peroxyacetyl nitrate (PAN) [Jacob and Wofsy, this issue]. Our dry season measurements of the diurnal behavior of $\mathrm{HCOOH}$ and $\mathrm{CH}_{3} \mathrm{COOH}$ within and just above the forest canopy in central Amazonia suggested that the acids have significant sources from both direct biogenic emissions and atmospheric reactions [Andreae et al., 1988a].

It has been suggested by Chameides and Davis [1983] that rapid aqueous phase oxidation of $\mathrm{H}_{2} \mathrm{C}(\mathrm{OH})_{2}$ by $\mathrm{OH}(\mathrm{aq})$ in clouds could be a major source of $\mathrm{HCOOH}$ in the remote troposphere. However, Jacob [1986] pointed out that cloud droplets can also be efficient sinks for $\mathrm{HCOOH}$ due to rapid oxidation of $\mathrm{HCOO}^{-}$by $\mathrm{HO}(\mathrm{aq})$, and for $p \mathrm{H}$ greater than five, clouds are not efficient $\mathrm{HCOOH}$ sources. Jacob and 


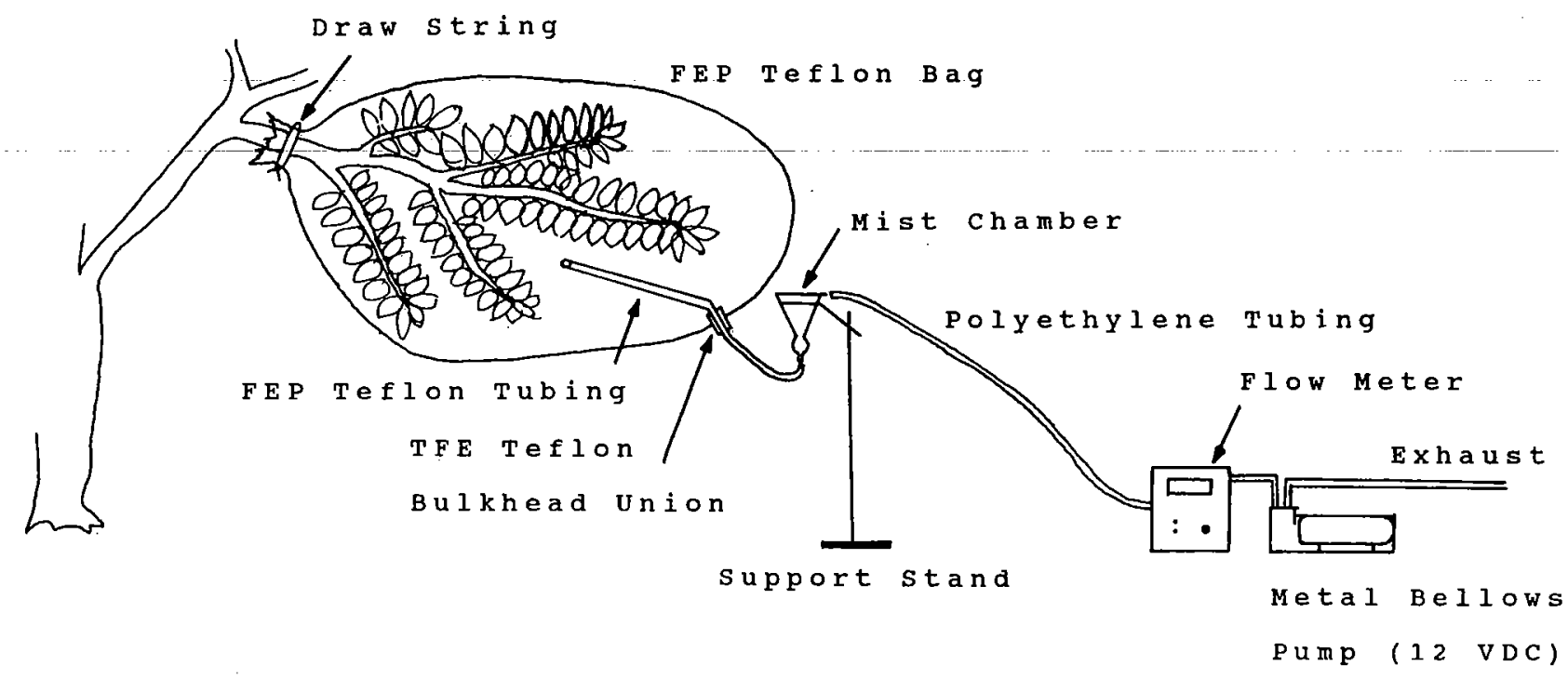

Fig. 1. Schematic representation of apparatus used to measure direct emission of carboxylic acids from Amazonia trees.

Wofsy [1988a] simulated the coupled gas and aqueous phase chemistry in clouds over the Amazon forest during the dry season and concluded that the aqueous phase was not a major source of $\mathrm{HCOOH}$ to mixed layer air. They also predicted that production of $\mathrm{CH}_{3} \mathrm{COOH}$ by aqueous phase reactions in clouds is negligibly slow.

In this paper we report the results of our carboxylic acid measurements during the April-May segment of the 1987 wet season in central Amazonia. We utilize data obtained in the forest canopy, the planetary boundary layer (PBL), and free troposphere, combined with a photochemical model, to evaluate potential biogenic and atmospheric sources and sinks of $\mathrm{HCOOH}, \mathrm{CH}_{3} \mathrm{COOH}$, and $\mathrm{CH}_{3} \mathrm{C}(\mathrm{O}) \mathrm{COOH}$ over the Amazon forest. The role of $\mathrm{HCOOH}$ and $\mathrm{CH}_{3} \mathrm{COOH}$ in wet season precipitation chemistry is discussed in a companion paper [Andreae et al., this issue (a)]. Here we focus on the gas phase carboxylic acid regime.

\section{Methods}

\subsection{Mist Chamber Technique}

Gas phase concentrations of selected carboxylic acids were determined using the mist chamber technique. We have developed this technique and extensively tested and evaluated it in our laboratory. The mist chamber technique for measuring gaseous carboxylic acids appears to be one of the most reliable methods at this time [Keene et al., 1989]. The details of this sampling technique for carboxylic acids have been described by Talbot et al. [1988]. Briefiy, the technique utilizes a mist of deionized water to efficiently strip soluble carboxylic species from the atmosphere and concentrate them in the aqueous phase. After sampling, the solution $(\approx 10 \mathrm{~mL})$ is withdrawn from the sampler, placed in a $15-\mathrm{mL}$ amber linear polyethylene bottle, and $\mathrm{CH}_{3} \mathrm{Cl}$ is added immediately to prevent biological degradation of the samples. Samples were usually analyzed the same day, and always within 24 hours after collection.

\subsection{Ground-Based Sampling}

Gaseous carboxylic acids were sampled from the micrometeorological tower located in the Ducke Forest Reserve $\left(2^{\circ} 56^{\prime} \mathrm{S}, 59^{\circ} 58^{\prime} \mathrm{W}\right)$ about $25 \mathrm{~km}$ north of Manaus in central Amazonas, Brazil. We obtained vertical profiles within and just above the forest canopy by sampling simultaneously at three heights above ground level: 12 or 19,35 , and $41 \mathrm{~m}$. Our sampling configuration consisted of mist chamber samplers mounted on the tower, while the pumping and flow measurement devices were housed at the base of the tower in a wooden structure. Polyethylene tubing was used to connect the samplers to the vacuum source. Sampled air was drawn through about $2 \mathrm{~m}$ of 1 -cm-diameter Teflon tubing, which extended horizontially out from the tower. We used $2-\mu \mathrm{m}$ pore sized Zefluor Teflon filters ( $47 \mathrm{~mm}$ diameter) housed in Teflon inline holders to remove particulate matter from the sampled airstream. Tests in our laboratory showed that losses of $\mathrm{HCOOH}$ and $\mathrm{CH}_{3} \mathrm{COOH}$ to the apparatus walls were negligible at levels of 300-500 parts per trillion by volume (ppt). Sample collection intervals were generally of 1-hour duration. Frequent interruptions in sampling were common due to intense tropical showers and associated electrical activity near the tower.

At the edge of a clearing at Ducke Forest Reserve, we performed preliminary measurements of direct emission of carboxylic acids by Amazonia trees. We enclosed a portion of a tree branch in a $1-\mathrm{m}^{-3}$ fluorinated ethylene propylene (FEP) Teflon bag and determined the carboxylic acid average concentrations inside over a 10 -min time interval (Figure 1). The selected branches were $2-3 \mathrm{~m}$ above ground level. One measurement was made per branch. Sampling began as soon as the branch was enclosed to minimize stress and possible perturbation of the emission rates. Although physical parameters such as temperature and humidity were not measured inside the enclosure, we believe that the conditions were not significantly different from ambient air. No condensation was observed on the interior surface of the Teflon bag. The bag was not completely sealed around the 
branch. Instead, it was left open just enough at one end to allow ambient air to be easily pulled into the bag as we collected the sample at $8 \mathrm{~L} \mathrm{~min}^{-1}$ from the center region of the bag. The measurements were conducted-between 0900 and $1100 \mathrm{LT}$, when the trees were at their photosynthetic maxima as evidenced from $\mathrm{CO}_{2}$ profiles through the canopy [Fan et al., this issue]. The ambient concentration of the carboxylic acids was monitored during the emission measurements with another sampler located about $10 \mathrm{~m}$ from the selected trees. Four different common tree species were surveyed before a severe tropical storm interrupted the measurements. Unfortunately, we were unable to obtain reliable information to correctly identify the actual tree species that we surveyed. We estimated the leaf surface area within the enclosure bag by counting the number of leaves and then measuring the dimensions of selected leaves.

\subsection{Aircraft Sampling}

Gas and particulate phase sampling of carboxylic acids was conducted aboard the NASA Electra research aircraft. The various flight scenarios are described elsewhere [Harriss et al., this issue]. The data reported here were obtained during missions designed to study the chemistry and vertical distribution of species in the low-to-middle troposphere associated with various scales of active convection. On one occasion, weather conditions permitted us to obtain data between Manaus and Belem located on the eastern coast of Amazonia.

For the gas phase, air was sampled using the mist chamber technique from a Teflon manifold ( $8 \mathrm{~mm}$ ID), which was continuously flushed at $50 \mathrm{~L} \mathrm{~min}^{-1}$ with outside air. As with the ground-based collections, we used a Tefion filter to remove aerosols from the sampled airstream. An integrating mass flowmeter was utilized to determine sampled air volumes. The overall uncertainty in atmospheric concentration is estimated to be $10 \%$, comprised primarily of analytical and flow measurement errors.

The aerosol sampling system and procedures are described in detail in a companion paper [Talbot et al., this issue]. The atmospheric aerosol was segragated into fine $(<1$ $\mu \mathrm{m})$ and coarse $(>1 \mu \mathrm{m})$ particle fractions using two sequential $90-\mathrm{mm}$-diameter filters mounted in polyethylene supports. Coarse mode particles were collected on a $8.0-\mu \mathrm{m}$ pore sized Nuclepore filter, while a $2-\mu \mathrm{m}$ nominal pore sized Zefluor Teflon filter retained the fine fraction. The sampling rate was about 175 standard liters per minute and was continuously adjusted to maintain isokinetic conditions. Filter samples were kept tightly sealed in polyethylene bags except during actual aerosol collection. One field blank was obtained for every three aerosol samples collected. Samples were extracted with water (Nuclepore) or a methanol-water sequence (Zefluor) and preserved with $\mathrm{CH}_{3} \mathrm{Cl}$ immediately after each aircraft mission. Chemical analysis was completed within 48 hours after sample collection. We estimate that the aerosol carboxylate concentrations have an uncertainty of $20 \%$, based on propagation of the various errors associated with the measurement. Variation in filter blank levels is the largest component (12\%) of the overall uncertainty.

\subsection{Chemical Analysis}

Carboxylic acid samples were analyzed by ion exchange chromatography using a Dionex HPIC-AS4 column and a weak bicarbonate eluent $\left(0.45 \mathrm{mmol} \mathrm{L}^{-1} \mathrm{NaHCO}_{3}\right)$. We confirmed these results, especially for $\mathrm{CH}_{3} \mathrm{COOH}$, by reanalyzing selected samples by Donnan exclusion chromatography utilizing a-Dionex HPICE-AS1-column- with-a-1-mmol $\mathrm{L}^{-1} \mathrm{HCl}$ eluent. The results from both chromatographic techniques agreed within $10 \%$, and usually 5\%. Aqueous standards of the acids were prepared from their sodium salts (Fluka), with $\mathrm{CHCl}_{3}$ (Aldrich, gold label) added to prevent microbial decomposition. Blanks were handled and analyzed in identical format as samples.

\section{Results AND Discussion}

\subsection{Distribution in Atmosphere Over Amazon Forest}

The mean atmospheric concentrations of gaseous $\mathrm{HCOOH}, \mathrm{CH}_{3} \mathrm{COOH}$, and $\mathrm{CH}_{3} \mathrm{C}(\mathrm{O}) \mathrm{COOH}$ at $150-\mathrm{m}$ altitude in the boundary layer were $430 \pm 225,340 \pm 155$, and $25 \pm 15$ ppt $(N=27)$, respectively. These concentrations are threefold lower for $\mathrm{HCOOH}$, fivefold for $\mathrm{CH}_{3} \mathrm{COOH}$, and sevenfold for $\mathrm{CH}_{3} \mathrm{C}(\mathrm{O}) \mathrm{COOH}$ from the levels that we observed during the 1985 dry season. Gaseous carboxylic acid concentrations in the boundary layer were highly variable and strongly influenced by precipitation events [Andreae et $a l$, this issue $(a)]$.

The frequency distributions of $\mathrm{HCOOH}, \mathrm{CH}_{3} \mathrm{COOH}$, and $\mathrm{CH}_{3} \mathrm{C}(\mathrm{O}) \mathrm{COOH}$ concentrations at $150-\mathrm{m}$ altitude in the boundary layer over central Amazonia are shown in Figure 2. For $\mathrm{CH}_{3} \mathrm{COOH}, 93 \%$ of the data were in the $100-500 \mathrm{ppt}$ range. In contrast, $\mathrm{HCOOH}$ and $\mathrm{CH}_{3} \mathrm{C}(\mathrm{O}) \mathrm{COOH}$ concentrations were highly variable within the ranges $100-1000$ and 5-60 ppt, respectively. In 10 of the 27 boundary layer samples collected at $150 \mathrm{~m}$, the $\mathrm{CH}_{3} \mathrm{C}(\mathrm{O}) \mathrm{COOH}$ concentration was below our detection limit of about $5 \mathrm{ppt}$. The variability in these data cannot be attributed to diel periodicities, as the majority of the measurements were performed around midday. The highest concentrations of carboxylic acids were observed during mission 16 (April 29), when the atmosphere over central Amazonia was strongly influenced by inflow of northern hemispheric air [Talbot et al., this issue].

The concentrations of $\mathrm{HCOOH}, \mathrm{CH}_{3} \mathrm{COOH}$, and $\mathrm{CH}_{3} \mathrm{C}(\mathrm{O}) \mathrm{COOH}$ in the free troposphere were much less variable than in the boundary layer. We observed at $5 \mathrm{~km}$ a mean concentration (ppt) of $170 \pm 40$ for $\mathrm{HCOOH}, 210 \pm 40$ for $\mathrm{CH}_{3} \mathrm{COOH}$, and $15 \pm 15$ for $\mathrm{CH}_{3} \mathrm{C}(\mathrm{O}) \mathrm{COOH}(N=15)$. Despite frequent precipitation in the boundary layer, $\mathrm{HCOOH}$ was enriched there 2.5-fold over free tropospheric air. The same was true for $\mathrm{CH}_{3} \mathrm{COOH}$ and $\mathrm{CH}_{3} \mathrm{C}(\mathrm{O}) \mathrm{COOH}$, but the enhancement was less, averaging only 1.6-fold. These relationships indicate that the Amazonia biosphere may be a source of atmospheric carboxylic acids.

Measurements of gaseous $\mathrm{HCOOH}$ in cross-basin flights illustrate the strong continental source for this species. Unfortunately, $\mathrm{CH}_{3} \mathrm{COOH}$ concentrations are not available for these flights due to a contamination problem. The distribution of $\mathrm{HCOOH}$ in the boundary layer across Amazonia eastward to the Atlantic Ocean is shown in Figure 3. The mean value for all data collected in the Manaus region during our wet season study period is also shown. The cross-basin flights were flown on April 23 (eastward legs) and April 24 (westward legs). The concentration of $\mathrm{HCOOH}$ decreased 

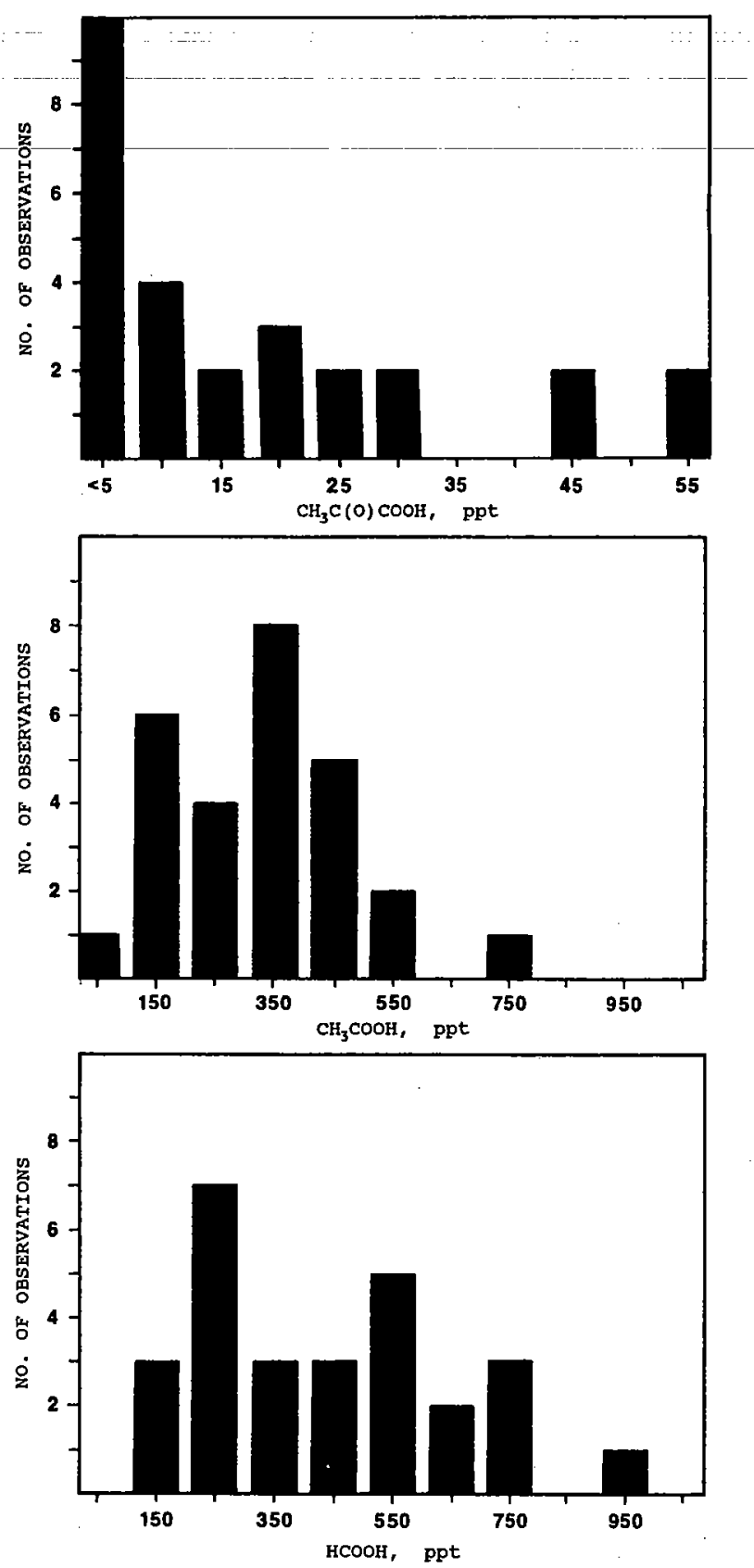

Fig. 2. Frequency distributions depicting the gas phase concentrations of $\mathrm{HCOOH}, \mathrm{CH}_{3} \mathrm{COOH}$, and $\mathrm{CH}_{3} \mathrm{C}(\mathrm{O}) \mathrm{COOH}$ in boundary layer air (0.15- to 2-km altitude) during the April-May 1987 study period.

steadily across Amazonia, reaching its lowest level over Atlantic coastal waters. Compared with the $30 \mathrm{ppt}$ level observed for $\mathrm{HCOOH}$ in marine air, the average concentration of $430 \mathrm{ppt}$ in the boundary layer over central Amazonia is 15 -fold higher. Some of the spatial variability is related to diurnal concentration changes. However, the sample collected in marine air was obtained during midafternoon hours, allowing a fairly direct comparison of the $\mathrm{HCOOH}$ concentration with the mean value for the central basin. We feel that these data indicate a strong continental signature for the $\mathrm{HCOOH}$ source over Amazonia.

The concentrations of $\mathrm{HCOO}^{-}, \mathrm{CH}_{3} \mathrm{COO}^{-}$, and $\mathrm{CH}_{3} \mathrm{C}(\mathrm{O}) \mathrm{COO}^{-}$in the atmospheric aerosol over Amazonia were usually below our detection limit of 5-10 ppt. On one occasion we observed elevated levels of these species in the particulate phase. This enhancement occurred during mission 16 (April 29), when we observed a large influx of soil dust into the central Amazon Basin. We have hypothesized that this material originated in Africa and possibly represented a mixture of Saharan dust and biomass-burning products [Talbot et al., this issue]. Acetate was particularly enhanced on April 29, reaching a concentration of $30 \mathrm{ppt}$. However, its gas phase concentration on that day was also much higher ( $730 \mathrm{ppt})$. The low concentrations in the aerosol relative to the gas phase are consistent with our observations for the dry season, where aerosol carboxylate concentrations in the boundary layer were around $25 \mathrm{ppt}$ compared with gas phase concentrations of $1500 \mathrm{ppt}$ [Andreae et al., 1988a]. Similar phase partitioning of these carboxylic acids has been observed in the atmosphere over temperate regions of North America and over marine areas [Andreae et al., 1987; Talbot et al., 1988].

\subsection{Distribution Through Forest Canopy and Vegetation Emissions}

Recent measurements of $\mathrm{HCOOH}$ and $\mathrm{CH}_{3} \mathrm{COOH}$ in the gas phase and precipitation at temperate and tropical continental sites have led to the hypothesis that vegetation may be the dominant source of these acids [Keene and Galloway, 1986; Talbot et al., 1988; Andreae et al., 1988a]. We determined the vertical distribution of gaseous $\mathrm{HCOOH}$, $\mathrm{CH}_{3} \mathrm{COOH}$, and $\mathrm{CH}_{3} \mathrm{C}(\mathrm{O}) \mathrm{COOH}$ through the forest canopy to gain insight on potential vegetative sources. In Figure 4, representative profiles through the canopy are shown for four different days (April 28 and 30, May 2 and 5). The highest concentrations of $\mathrm{HCOOH}, \mathrm{CH}_{3} \mathrm{COOH}$, and $\mathrm{CH}_{3} \mathrm{C}(\mathrm{O}) \mathrm{COOH}$ consistently occurred at our uppermost sampling height $(41 \mathrm{~m})$, about $10 \mathrm{~m}$ above the mean canopy top. The lowest concentrations of these carboxylic acids were at ground level $(1.5 \mathrm{~m})$. The concentrations within and above the canopy show a daily temporal trend of rapid increase from early morning to midafternoon and then a decrease beginning around 1500 LT. To illustrate this daily pattern better, we show data from the 41-m location as a function of time in Figure 5. We obtained data through the night on one occasion, but the data were compromised by apparent pollution from nearby Manaus. Concentrations of NO measured by the Harvard group on that night showed intermittent high values believed to reflect transport of fresh anthropogenic emissions to our sampling site [Bakwin et al., this issue]. The carboxylic acid concentrations increased by a factor of 2 during this time period. These data have been omitted from our analysis here, since various anthropogenic activities are known to be sources of atmospheric $\mathrm{HCOOH}$ and $\mathrm{CH}_{3} \mathrm{COOH}$ [Talbot et al., 1988].

The observed diurnal behavior of the carboxylic acids suggest a daytime source followed by removal from the atmosphere during the evening and nighttime. We observed a similar diurnal signal for these acids during the dry season in Amazonia [Andreae et al., 1988a] and at a site in eastern Virginia [Talbot et al., 1988]. The near-surface diurnal cycle in atmospheric carboxylic acids is strikingly similar to that observed for isoprene in Amazonia [Rasmussen and Khalil, 1988]. This similarity and the known vegetative source for isoprene point to the biosphere as a potential source of 


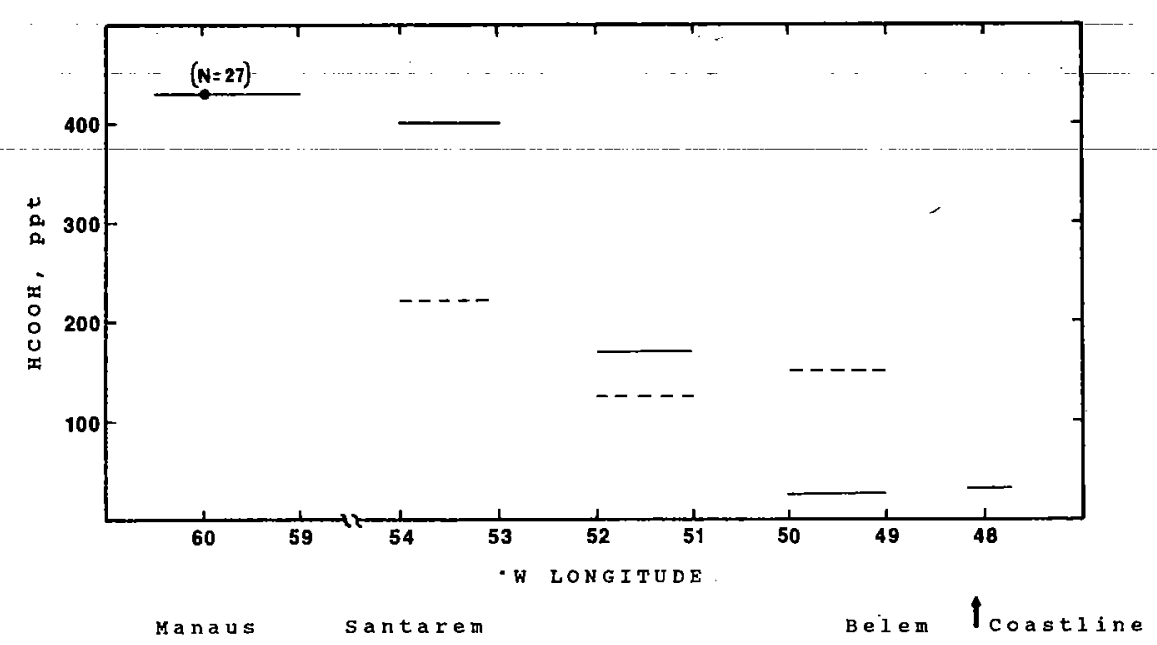

Fig. 3. Geographic trend in the concentration of $\mathrm{HCOOH}$ in the atmospheric boundary layer along a transect from Manaus in central Amazonia to the Atlantic Ocean (solid lines) and returning (dashed lines). The length of the lines refers to the geographic area covered by individual samples. The mean boundary layer concentration ubserved in central Amazonia during the April-May 1987 study period is also shown.

atmospheric $\mathrm{HCOOH}, \mathrm{CH}_{3} \mathrm{COOH}$, and $\mathrm{CH}_{3} \mathrm{C}(\mathrm{O}) \mathrm{COOH}$. The pronounced enhancement of these species in daytime boundary layer air is most likely related to biogenic emissions or atmospheric photochemical processes. In the absence of precipitation, removal of carboxylic species from the atmosphere during the nighttime is probably primarily by dry deposition to the forest canopy, as known chemical loss mechanisms are too slow [Jacob and Wofsy, 1988a].

At the very end of our wet season study period, we obtained some preliminary data on direct emission of carboxylic acids from Amazonian trees. The estimated direct emission rates of $\mathrm{HCOOH}, \mathrm{CH}_{3} \mathrm{COOH}$, and $\mathrm{CH}_{3} \mathrm{C}(\mathrm{O}) \mathrm{COOH}$ are shown in Table 1. We observed rapid enhancement over ambient levels inside the enclosure bags within 10 min which are attributed to direct emissions from the tree leaves. We interpret these measurements as representing net vegetative direct emissions to the atmosphere; the instantaneous fluxes were not determined, and deposition back to the leaf surface could have occurred during the sampling interval. Concentrations of $\mathrm{HCOOH}$ and $\mathrm{CH}_{3} \mathrm{COOH}$ as high as $7000 \mathrm{ppt}$ were measured in the bag, while ambient levels were 400-600 ppt. Surprisingly, the same was found for $\mathrm{CH}_{3} \mathrm{C}(\mathrm{O}) \mathrm{COOH}$, where the ambient level was about 35 ppt compared with 100-1000 ppt inside the bag. Among the trees surveyed, we found an order of magnitude variation in the emission rates of the various carboxylic acids. The mean emission fluxes in $\mathrm{nmol} \mathrm{m}^{-2}$ $\mathrm{min}^{-1}$ were $0.66,1.4$, and 0.14 for $\mathrm{HCOOH}, \mathrm{CH}_{3} \mathrm{COOH}$, and $\mathrm{CH}_{3} \mathrm{C}(\mathrm{O}) \mathrm{COOH}$, respectively.

There appeared to be no relationship between tree species in the emission of various acids, as the ratios $\mathrm{HCOOH} /$ $\mathrm{CH}_{3} \mathrm{COOH}$ and $\mathrm{HCOOH} / \mathrm{CH}_{3} \mathrm{C}(\mathrm{O}) \mathrm{COOH}$ varied $40-$ and 35 -fold, respectively. The ratio determined from the mean emission flux of each acid $\left(\mathrm{HCOOH} / \mathrm{CH}_{3} \mathrm{COOH}=1.1\right.$ and $\left.\mathrm{HCOOH} / \mathrm{CH}_{3} \mathrm{C}(\mathrm{O}) \mathrm{COOH}=16\right)$ is similar to values that we observed in and above the forest canopy. However, direct comparison with observed atmospheric concentration ratios is difficult because the acids have different lifetimes. Our measurements indicate that direct emissions of $\mathrm{HCOOH}$, $\mathrm{CH}_{3} \mathrm{COOH}$, and $\mathrm{CH}_{3} \mathrm{C}(\mathrm{O}) \mathrm{COOH}$ from trees are a source of these species to the atmosphere over the Amazon Basin. In section 4 of this paper we compare this primary biogenic source to various secondary sources.

\subsection{Vertical Gradients and Relationships in the Gas Phase}

To gain further insight on sources and sinks of carboxylic acids in the atmosphere over the Amazon forest, we examined the vertical gradients in concentration and the interspecies relationships. We calculated the mean concentrations of $\mathrm{HCOOH}, \mathrm{CH}_{3} \mathrm{COOH}$, and $\mathrm{CH}_{3} \mathrm{C}(\mathrm{O}) \mathrm{COOH}$ for five altitude ranges and present this summary in Table 2 . Only concentrations measured over the central Amazon Basin were included in the aircraft-based boundary layer data. The carboxylic acid concentrations measured both in and above the canopy are not significantly different (at $P=0.10$ level) from the aircraft-based boundary layer measurements. However, the concentrations observed under the canopy $(1.5 \mathrm{~m})$ are significantly lower $(P=\mathbf{0 . 1 0})$ than those higher up in the canopy and boundary layer. The low concentrations under the canopy indicate that ground-based emissions of carboxylic acids (e.g., from soil or ants) must be small relative to canopy emissions (e.g., from vegetation) and atmospheric production. However, it is not obvious from Tables 1 and 2 how canopy emissions compare with atmospheric production. The lack of a significant concentration gradient between the canopy top and the boundary layer $(150-2000 \mathrm{~m})$ seems difficult to explain on the basis of canopy emissions only, since the rapid removal of carboxylic acids by wet deposition should preclude the mixing of canopy emissions over such a deep layer. The model calculations presented in section 4 suggest that atmospheric production may provide the principal source of carboxylic acids in the boundary layer over the Amazon forest.

We examined our data for $\mathrm{CH}_{3} \mathrm{C}(\mathrm{O}) \mathrm{COOH}$ in more detail to look for possible direct effects of convection. Pyruvic acid photolyzes in the daytime (lifetime of a few hours), so that its distribution may give insights into the rates of vertical transport. On two occasions, we sampled during flights 

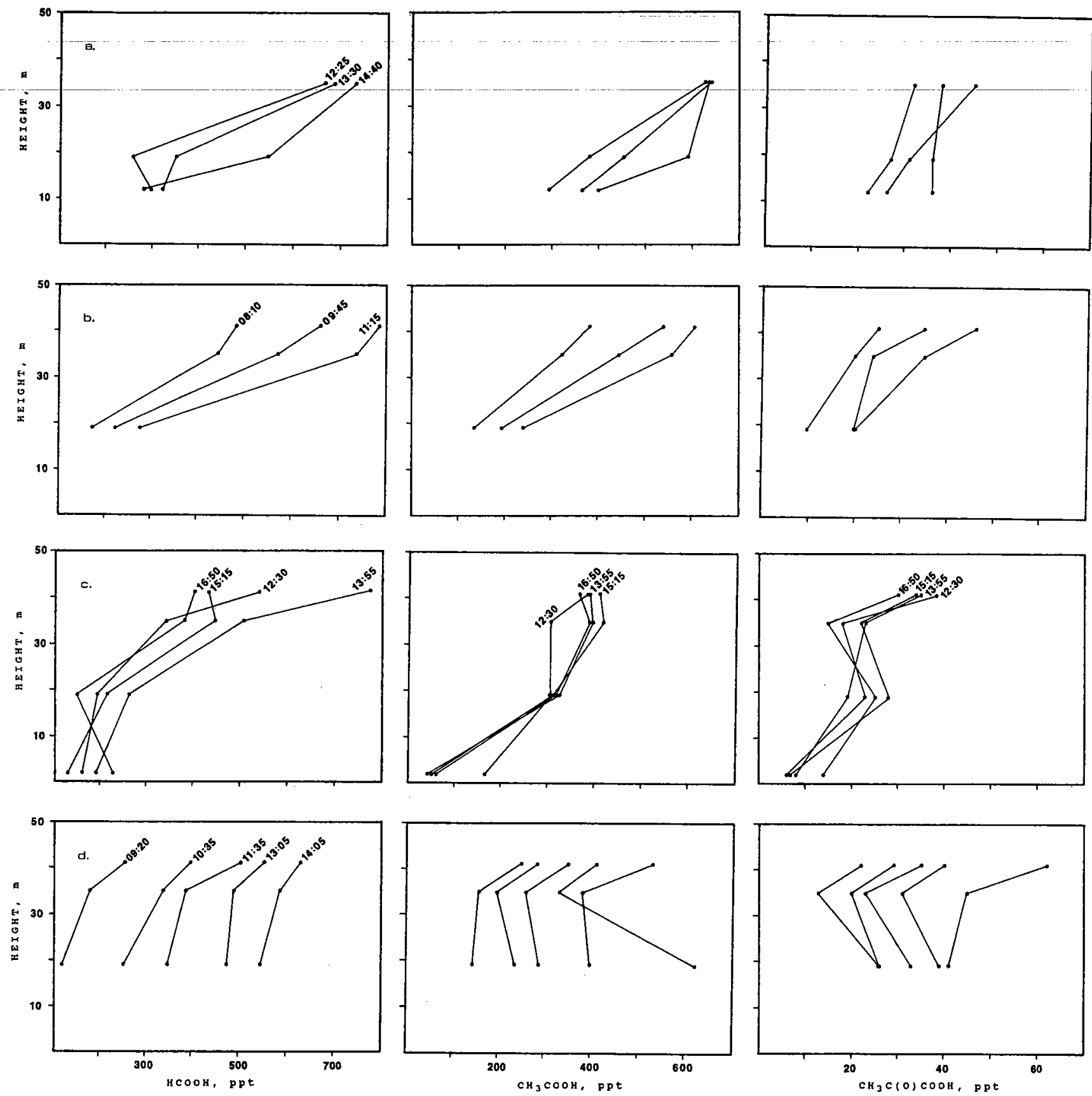

Fig. 4. Vertical profiles of $\mathrm{HCOOH}, \mathrm{CH}_{3} \mathrm{COOH}$, and $\mathrm{CH}_{3} \mathrm{C}(\mathrm{O}) \mathrm{COOH}$ in the gas phase through the terra firme forest canopy at Ducke Forest Reserve. The local time corresponding to the midpoint of the sampling interval is indicated above each $\mathrm{HCOOH}$ profile. Times shown for $\mathrm{HCOOH}$ also correspond to the $\mathrm{CH}_{3} \mathrm{COOH}_{\text {and }}$ $\mathrm{CH}_{3} \mathrm{C}(\mathrm{O}) \mathrm{COOH}$ profiles (following sequence of uppermost sampling height) except where indicated for May $2,1987$. Total sampling time for individual profiles averaged $80 \mathrm{~min}$. Profiles were obtained on (a) April 28, (b) April 30, (c) May 2, and (d) May 5, 1987.

where the aircraft flew in a triangular pattern at both 0.15 and $4.5-\mathrm{km}$ altitude as a convective system moved through the enclosed area. The flight path intercepted potential cloud draft inflow and outflow regions. The concentration of $\mathrm{CH}_{3} \mathrm{C}(\mathrm{O}) \mathrm{COOH}$ at $4.5 \mathrm{~km}$ during these flights was about 50 ppt, the same as it was in the boundary layer (Figure 6). The mean concentration of $\mathrm{CH}_{3} \mathrm{C}(\mathrm{O}) \mathrm{COOH}$ in the free troposphere, with data for missions 7 and 20 omitted, was $9 \pm 5$ ppt. We thus observed fivefold enhancement in $\mathrm{CH}_{3} \mathrm{C}(\mathrm{O}) \mathrm{COOH}$ concentration at $4.5 \mathrm{~km}$ during missions 7 and 20 compared with the average concentration observed for all other missions. The concentration of $\mathrm{HCOOH}$ was also enhanced at $4.5 \mathrm{~km}$ during mission 7 (435 ppt compared with $170 \pm 40 \mathrm{ppt})$, but not during mission 20 (195 ppt). No enhancement at $4.5 \mathrm{~km}$ was observed for $\mathrm{CH}_{3} \mathrm{COOH}$ during either mission $(P=0.05)$. The data for $\mathrm{CH}_{3} \mathrm{C}(\mathrm{O}) \mathrm{COOH}$ support the idea that rapid convective transport plays a role in determining the vertical distribution of species in the atmosphere over the Amazon forest during the wet season.

Examination of the vertical distribution of 

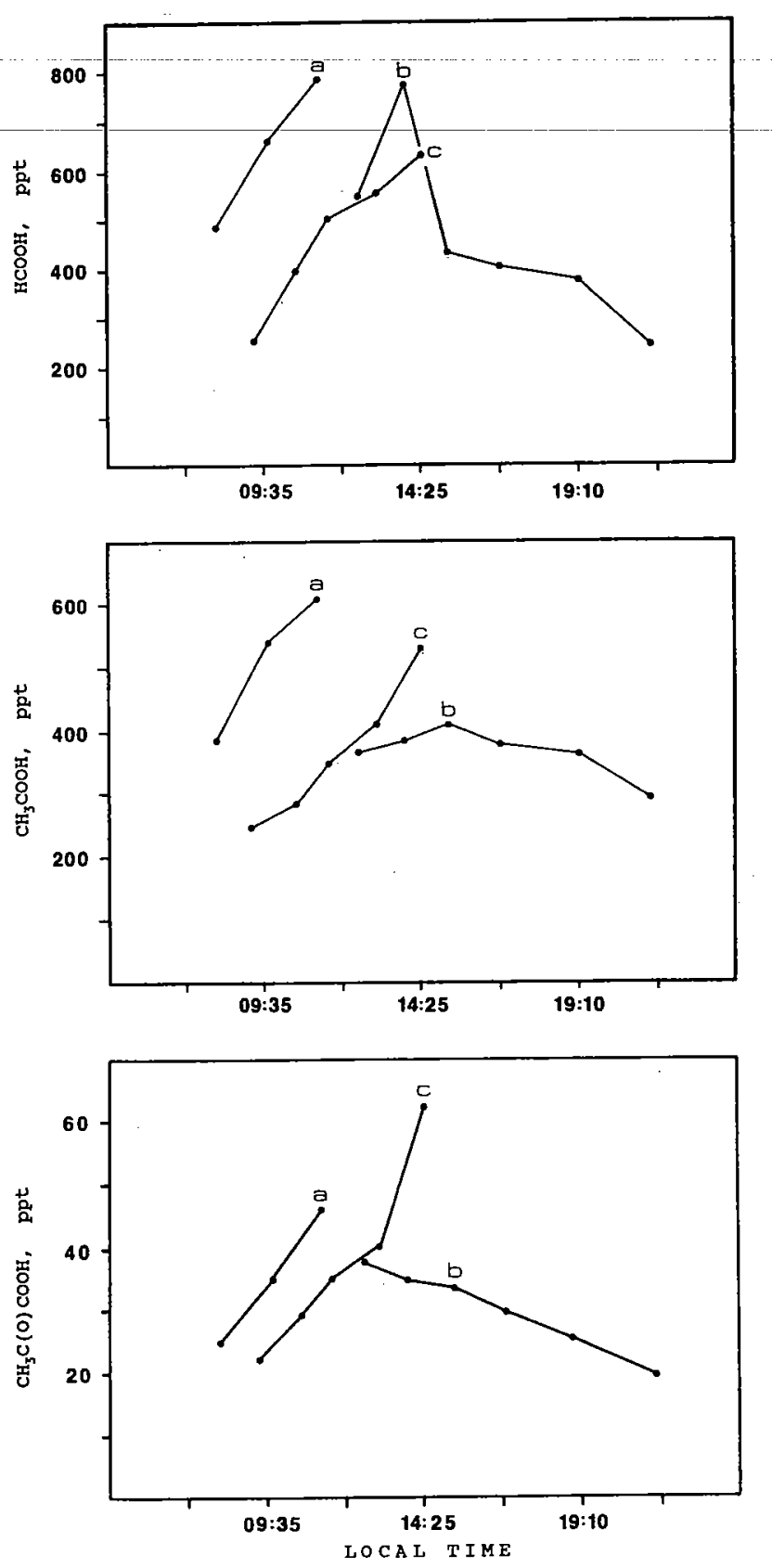

Fig. 5. Diurnal variation of $\mathrm{HCOOH}, \mathrm{CH}_{3} \mathrm{COOH}$, and $\mathrm{CH}_{3} \mathrm{C}(\mathrm{O}) \mathrm{COOH}$ in the gas phase above the terra firme forest canopy at Ducke Forest Reserve. Data correspond to measurements performed at 41-m altitude on (a) April 30, (b) May 2, and (c) May 5 (see Figure 4).

$\mathrm{CH}_{3} \mathrm{C}(\mathrm{O}) \mathrm{COOH}$ over Amazonia, with the free tropospheric values for missions 7 and 20 removed, shows that its boundary layer concentration was on the average signifcantly higher than in the free troposphere $(P=0.10)$. It appears that the vertical gradients in $\mathrm{CH}_{3} \mathrm{C}(\mathrm{O}) \mathrm{COOH}$ and $\mathrm{HCOOH}$ are indeed very similar.

The relationship between the various carboxylic acids provides clues to their sources and sinks. We examined the relationships $\mathrm{HCOOH} / \mathrm{CH}_{3} \mathrm{COOH}$ and $\mathrm{HCOOH} /$ $\mathrm{CH}_{3} \mathrm{C}(\mathrm{O}) \mathrm{COOH}$ at various heights in the atmosphere over Amazonia (Figures 7 and 8). At all altitudes in the boundary layer, $\mathrm{HCOOH}$ and $\mathrm{CH}_{3} \mathrm{COOH}$ concentrations appear to be correlated linearly, especially just above the forest canopy. We used the reduced major axis (RMA) method to derive the relationship between the carboxyl species [Miller and Kahn, 1962]. The-results of this-analysis-are-summarized in Table-3. There is a progressive increase in the value of the ratio $\mathrm{HCOOH} / \mathrm{CH}_{3} \mathrm{COOH}$ going from in the canopy to just above it and upward into the boundary layer. This trend suggests a proportionately larger source of $\mathrm{HCOOH}$ compared with $\mathrm{CH}_{3} \mathrm{COOH}$ in boundary layer air. Although there appears to be little correlation between $\mathrm{HCOOH}$ and $\mathrm{CH}_{3} \mathrm{COOH}$ in free tropospheric air, the dynamic range in concentration variation is confined to $120-260$ ppt. With such limited variation in concentration, it is not possible to reliably ascertain the relationship $\mathrm{HCOOH} / \mathrm{CH}_{3} \mathrm{COOH}$ for these data.

The RMA analysis for $\mathrm{HCOOH}$ and $\mathrm{CH}_{3} \mathrm{C}(\mathrm{O}) \mathrm{COOH}$ showed the same slope in the canopy and boundary layer. However, in boundary layer air the $r^{2}$ value was very low, indicating little correlation there between $\mathrm{HCOOH}$ and $\mathrm{CH}_{3} \mathrm{C}(\mathrm{O}) \mathrm{COOH}$ concentrations. In addition, the value of the ratio $\mathrm{HCOOH} / \mathrm{CH}_{3} \mathrm{C}(\mathrm{O}) \mathrm{COOH}$ just above the forest canopy (14) was much less than a photochemical source from isoprene decomposition over Amazonia should produce (i.e., 25-50) [Jacob and Wofsy, 1988a, b]. The direct source of $\mathrm{CH}_{3} \mathrm{C}(\mathrm{O}) \mathrm{COOH}$ from Amazonia trees is a likely cause for this result.

\section{Modeling of Carboxylic Acid Concentrations OVER THE AMAZON FOREST}

We use the photochemical model of Jacob and Wofsy [this issue] to estimate the contributions from various sources to the carboxylic acid concentrations over the Amazon forest. The model was developed to simulate the atmospheric composition observed during the Amazon Boundary Layer Experiment (ABLE 2B); it includes a detailed gas phase photochemical mechanism, and a one-dimensional representation of vertical transport within the canopy and in the boundary layer (up to $2000 \mathrm{~m}$ ). Simulations of observations for $\mathrm{O}_{3}, \mathrm{NO}, \mathrm{PAN}, \mathrm{NO}_{y}$, and sulfur species suggest that the model provides a reasonable representation of chemistry and vertical transport in the boundary layer over the forest [Jacob and Wofsy, this issue; Andreae et al., this issue (b)]. Carboxylic acids in the model are emitted directly by vegetation and are also produced by a number of atmospheric reactions. Ground-based emissions from soils or ants are assumed negligible (cf. section 3.3). Sinks for carboxylic acids include wet and dry deposition, reaction with $\mathrm{OH}$, and photolysis (for $\mathrm{CH}_{3} \mathrm{C}(\mathrm{O}) \mathrm{COOH}$ ).

Atmospheric sources of $\mathrm{HCOOH}$ in the model include the ozonolysis reactions of isoprene, methacrolein, and methylvinylketone; the latter reaction is also a source of $\mathrm{CH}_{3} \mathrm{C}(\mathrm{O}) \mathrm{COOH}[\mathrm{Jacob}$ and Wofsy, 1988a, b]. In clouds, aqueous phase oxidation of $\mathrm{CH}_{2} \mathrm{O}$ provides an additional source of $\mathrm{HCOOH}$ [Chameides, 1984]. Production of $\mathrm{HCOOH}$ by the $\mathrm{CH}_{2} \mathrm{O}+\mathrm{HO}_{2}$ reaction is negligible [cf. Jacob and Wofsy, 1988a]. Acetic acid is produced in the model by the reactions $\mathrm{CH}_{3} \mathrm{CO}_{3}+\mathrm{HO}_{2}$ and $\mathrm{CH}_{3} \mathrm{CO}_{3}+$ $\mathrm{CH}_{3} \mathrm{O}_{2}$ [Moortgat et al., 1989a, b], where the $\mathrm{CH}_{3} \mathrm{CO}_{3}$ radicals are supplied by atmospheric decomposition of isoprene and acetaldehyde. Aqueous phase sources of $\mathrm{CH}_{3} \mathrm{COOH}$ in cloud (oxidation of acetaldehyde, hydrolysis of peroxyacetic acid) are negligibly slow [Jacob and Wofsy, $1988 b]$. 
TABLE 1. Measurements of Net Direct Emissions of Carboxylic Acids by Amazonian Trees

\begin{tabular}{|c|c|c|c|c|c|c|}
\hline \multirow{2}{*}{$\begin{array}{l}\text { Area per } \\
\text { Leaf }^{*}, \mathrm{~cm}^{2}\end{array}$} & \multirow{2}{*}{$\begin{array}{l}\text { Full } \\
\text { Sunt, } \%\end{array}$} & \multicolumn{5}{|c|}{ Emission Flux $\ddagger$} \\
\hline & & HFo & HAC & HPy & $\mathrm{HFo} / \mathrm{HAC}$ & HFo/HPy \\
\hline 30 & 100 & 1.5 & 0.42 & 0.027 & 3.6 & 56 \\
\hline 30 & 75 & 0.79 & 3.2 & 0.43 & 0.25 & 1.8 \\
\hline 140 & 50 & 0.14 & 1.5 & 0.087 & 0.09 & 1.6 \\
\hline 700 & 80 & 0.20 & 0.32 & 0.033 & 0.63 & 6.1 \\
\hline Mean & & 0.66 & 1.4 & 0.14 & & \\
\hline
\end{tabular}

Measurements were performed between 0900 and 1100 LT on May 6, 1987, in terra firma forest at Ducke Forest Reserve. Each line entry corresponds to a different tree species. HFo, formic acid; HAc, acetic acid; and HPy, pyruvic acid. Represents net flux, i.e., instantaneous flux minus deposition during measurement interval (see text).

*Represents one side only.

†Indicates percentage of measurement interval where vegetation was exposed to direct solar irradiation. Cumulus were constantly building throughout the morning and intermittently blocked direct solar radiation.

$\ddagger$ Flux is expressed in nanomoles per meter squared of leaf per minute.

Vegetative emissions of carboxylic acids in the model are assumed to vary with temperature and light intensity, in the same way as isoprene emission [Jacob and Wofsy, this issue]. The emission fluxes are scaled to the isoprene emission flux, with scaling factors $(6 \%$ for $\mathrm{HCOOH}, 5 \%$ for $\mathrm{CH}_{3} \mathrm{COOH}$, and $0.3 \%$ for $\mathrm{CH}_{3} \mathrm{C}(\mathrm{O}) \mathrm{COOH}$ ) adjusted to provide a good simulation of the observed midday concentrations of each acid at canopy top. Emission is balanced partly by dry deposition to the leaves, which is simulated using a multilevel resistance-in-series scheme [Meyers and Baldocchi, 1988]. At night the forest is a slow sink for carboxylic acids, due to deposition at the cuticular surfaces of leaves (a cuticular resistance of $200 \mathrm{~s} \mathrm{~cm}^{-1}$ per cm $\mathrm{cm}^{2}$ of leaf is assumed). In addition to this dry deposition sink the carboxylic acids are also removed from the boundary layer by wet deposition, with a time constant of 1 day [Andreae et al., this issue $(a)]$.

The results presented here are taken from the standard model calculation of Jacob and Wofsy [this issue], which is discussed in detail in that paper. The simulation was conducted over three diurnal cycles, starting from observed mean free troposphere concentrations (Table 2) as initial conditions. This initialization is intended to simulate the passage of a major meteorological disturbance, when air from the free trosposphere is rapidly mixed with the PBL [Scala et al., this issue]. It is assumed that relatively undisturbed conditions follow the initial disturbance and persist for the duration of the model simulation. By model day 3 the concentrations of carboxylic acids have approached a steady state due to the short time constant for wet deposition; our presentation will focus on results from model day 3. Aqueous phase reactions in cloud are not included in the model calculation but are considered separately in sensitivity calculations discussed below.

Simulated vertical fluxes of carboxylic acids at canopy top are shown in Figure 9 as a function of time of day. The 24-hour average fluxes are $4.4 \times 10^{9}$ molecules $\mathrm{cm}^{-2} \mathrm{~s}^{-1}$ for $\mathrm{HCOOH}, 3.7 \times 10^{9}$ molecules $\mathrm{cm}^{-2} \mathrm{~s}^{-1}$ for $\mathrm{CH}_{3} \mathrm{COOH}$; and $2.8 \times 10^{8}$ molecules $\mathrm{cm}^{-2} \mathrm{~s}^{-1}$ for $\mathrm{CH}_{3} \mathrm{C}(\mathrm{O}) \mathrm{COOH}$. These values may be compared with the emission rates measured in the branch enclosures (Table 1). Assuming that the leaves sampled in the enclosures were representative of the forest vegetation, and assuming a canopy leaf index of 7 [Fan et al., this issue], then the mean emission fluxes given in Table 2 correspond to total canopy fluxes of $4.6 \times 10^{9}$ molecules $\mathrm{cm}^{-2} \mathrm{~s}^{-1}$ for $\mathrm{HCOOH}, 9.8 \times 10^{9}$ molecules $\mathrm{cm}^{-2}$ $\mathrm{s}^{-1}$ for $\mathrm{CH}_{3} \mathrm{COOH}$, and $9.8 \times 10^{8}$ molecules $\mathrm{cm}^{-2} \mathrm{~s}^{-1}$ for $\mathrm{CH}_{3} \mathrm{C}(\mathrm{O}) \mathrm{COOH}$. This extrapolation of the enclosure data may be somewhat biased because the measurements were taken at 0900-1100 LT, and near the edge of a clearing; the leaves were therefore exposed to higher-than-average sunshine. Overall, and considering the scatter in the data, the emission fluxes simulated by the model may be viewed as reasonably consistent with the branch enclosure measurements.

The simulated concentrations within the canopy (Figure

TABLE 2. Summary of Gas Phase Carboxylic Acids Over the Central Amazon Basin

\begin{tabular}{|c|c|c|c|c|}
\hline \multirow[b]{2}{*}{ Region } & \multicolumn{4}{|c|}{ Mean $\pm \sigma, \mathrm{ppt}$} \\
\hline & Formic & Acetic & Pyruvic & $N$ \\
\hline $\begin{array}{l}\text { Free troposphere } \\
3-5 \mathrm{~km}\end{array}$ & $170 \pm 40$ & $210 \pm 40$ & $15 \pm 15$ & 15 \\
\hline $\begin{array}{c}\text { Boundary layer } \\
0.15-2 \mathrm{~km}\end{array}$ & $430 \pm 225$ & $340 \pm 155$ & $25 \pm 15$ & 27 \\
\hline $\begin{array}{l}\text { Above canopy } \\
35-41 \mathrm{~m}\end{array}$ & $510 \pm 150$ & $410 \pm 120$ & $30 \pm 10$ & 31 \\
\hline $\begin{array}{l}\text { In canopy } \\
12-19 \mathrm{~m}\end{array}$ & $295 \pm 120$ & $335 \pm 125$ & $25 \pm 10$ & 18 \\
\hline $\begin{array}{l}\text { Under Canopy } \\
1.5 \mathrm{~m}\end{array}$ & $190 \pm 45$ & $100 \pm 105$ & $10 \pm 5$ & 5 \\
\hline
\end{tabular}

Measurements associated with forest canopy were performed from the $45-\mathrm{m}$ micrometeorological tower located at Ducke Forest Reserve. $N$ represents the number of observations. 

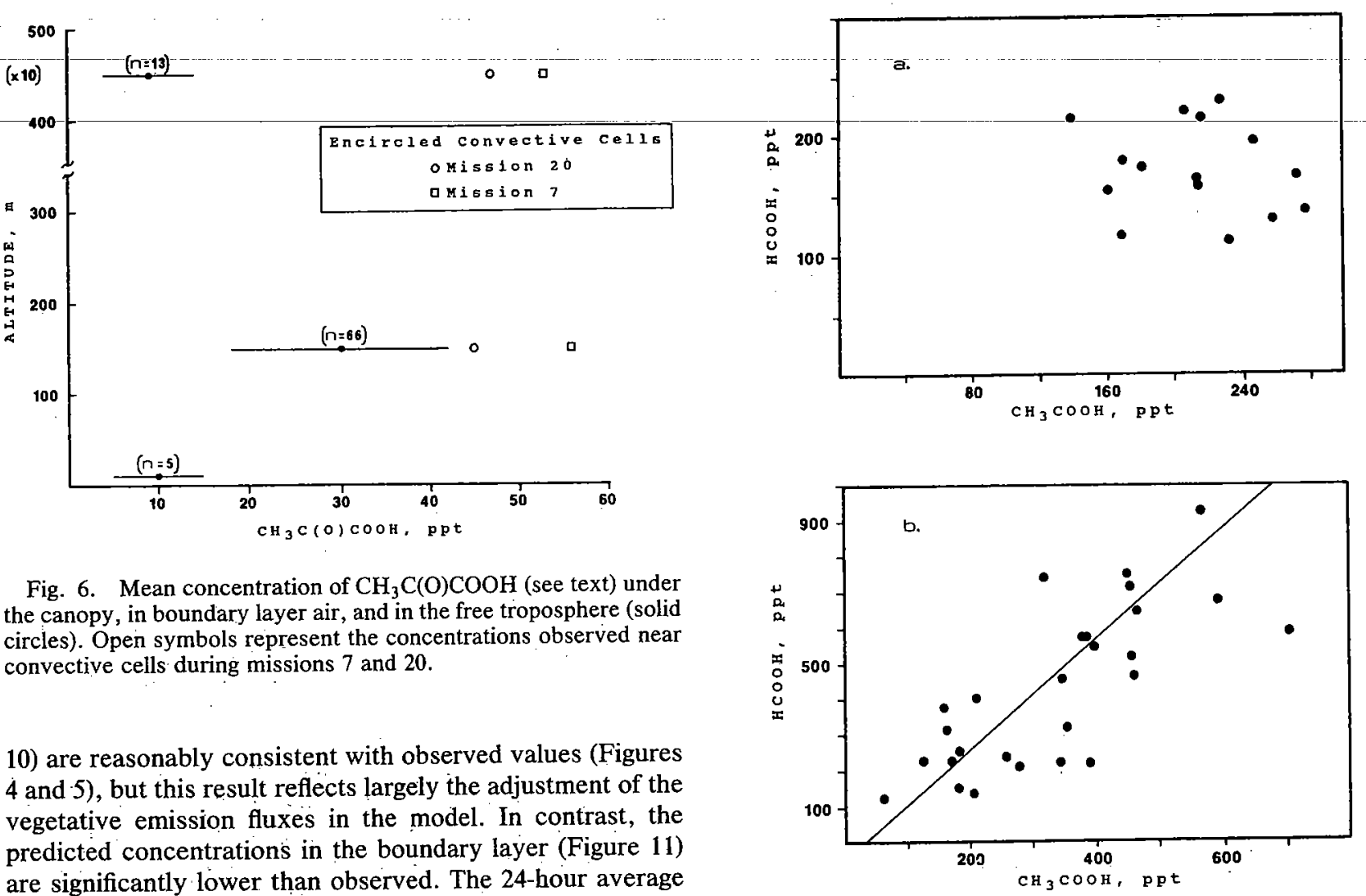

10) are reasonably consistent with observed values (Figures 4 and 5), but this result reflects largely the adjustment of the vegetative emission fluxes in the model. In contrast, the predicted concentrations in the boundary layer (Figure 11) are significantly lower than observed. The 24-hour average concentrations in the model boundary layer $(30-2000 \mathrm{~m})$ are 156,153 , and 5 ppt for $\mathrm{HCOOH}, \mathrm{CH}_{3} \mathrm{COOH}$, and $\mathrm{CH}_{3} \mathrm{C}(\mathrm{O}) \mathrm{COOH}$, respectively (Table 4), while the mean observed values for the altitude range $150-2000 \mathrm{~m}$ are 430 , 340 , and 25 ppt (Table 2). Although most of the observations were made in the daytime, the diurnal variation of concentrations in the model is small (Figure 11), so that the timing of the observations could not account for the difference with model results.

A likely explanation for the discrepancies between model and observations is that importanit sources of carboxylic acids in the boundary layer are missing from the model. We advance this explanation because the sources and sinks regulating the concentrations in the model (Table 4) appear to be relatively well constrained. Wet deposition, which is the principal sink for $\mathrm{HCOOH}$ and $\mathrm{CH}_{3} \mathrm{COOH}$, is constrained by the observed rainfall fluxes [Andreae et al., this issue (a)]. Vegetative emissions are constrained by the observed concentrations at canopy top, and by the canopy ventilation rates which are specified in the model on the basis of data for $\mathrm{O}_{3}, \mathrm{CO}_{2}$, and ${ }^{222} \mathrm{Rn}$ concentrations and fluxes [ Jacob and Wofsy, this issue]. Production of $\mathrm{HCOOH}$ and $\mathrm{CH}_{3} \mathrm{C}(\mathrm{O}) \mathrm{COOH}$ by ozonolysis of isoprene, methylvinylketone, and methacrolein could be underpredicted by probably no more than a factor of 2 , reflecting the uncertainty on the fate of the Criegee biradical intermediates [Atkinson and Lloyd, 1984]. Finally, the rates of $\mathrm{CH}_{3} \mathrm{COOH}$ production by the reactions $\mathrm{CH}_{3} \mathrm{CO}_{3}+\mathrm{CH}_{3} \mathrm{O}_{2}$ and $\mathrm{CH}_{3} \mathrm{CO}_{3}+\mathrm{HO}_{2}$ should be faịly reliable, since the concentrations of these peroxy radicals show little sensitivity to model conditions [Jacob and Wofsy, this issue].

The possibility of $\mathrm{HCOOH}$ production by aqueous phase oxidation of $\mathrm{CH}_{2} \mathrm{O}$ in cloud was examined in a sensitivity calculation which assumed instantaneous formation of a nonprecipitating cloud at $800-\mathrm{m}$ altitude at noon, and simu-
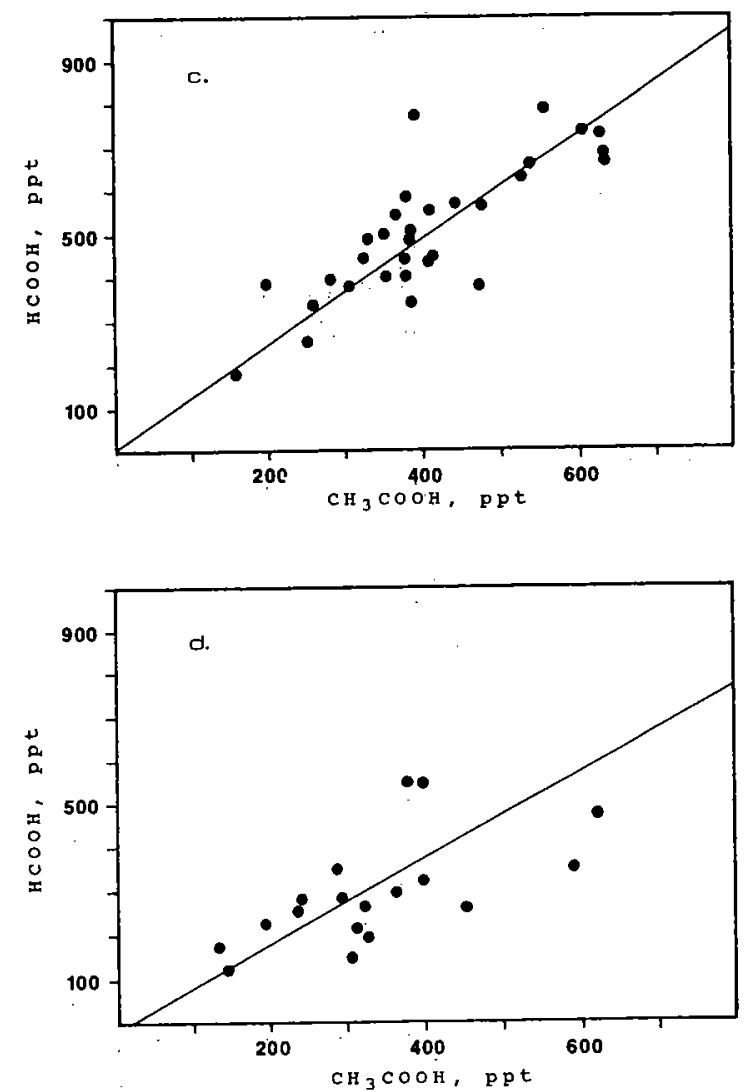

Fig. 7. Relationship between $\mathrm{HCOOH}$ and $\mathrm{CH}_{3} \mathrm{COOH}$ in the gas phase at various altitudes over the Amazon forest: (a) free troposphere $3-5 \mathrm{~km},(b)$ boundary layer $0.15-2 \mathrm{~km},(c)$ just above forest canopy $35-41 \mathrm{~m}$, and $(d)$ directly within forest canopy $12-19$ m. RMA regression lines are also shown. 

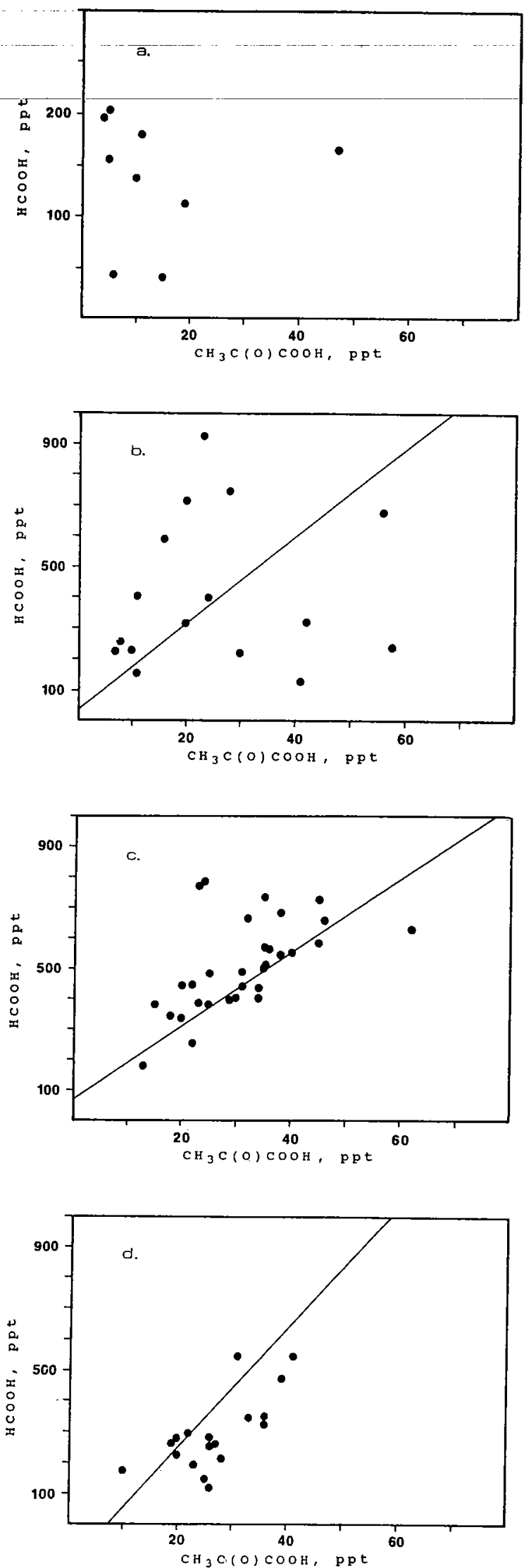

Fig. 8. Relationship between $\mathrm{HCOOH}$ and $\mathrm{CH}_{3} \mathrm{C}(\mathrm{O}) \mathrm{COOH}$ in the gas phase at various altitudes over the Amazon forest: $(a)$ free troposphere 3-5 km, (b) boundary layer $0.15-2 \mathrm{~km},(c)$ just above forest canopy $35-41 \mathrm{~m}$, and $(d)$ directly within forest canopy 12-19 m. RMA regression lines are also shown.
TABLE 3. Results of RMA Regression Analysis

\begin{tabular}{cccccccc}
\hline & \multicolumn{2}{c}{ Formic Versus Acetic } & \multicolumn{3}{c}{ Formic Versus Pyruvic } \\
\cline { 2 - 4 } Region & Slope & Intercept & $r^{2}$ & & Slope & Intercept & $r^{2}$ \\
\hline $\begin{array}{c}\text { Boundary } \\
\text { layer } \\
\quad 0.15-2 \mathrm{~km}\end{array}$ & 1.4 & -52 & 0.74 & 15 & +38 & 0.13 \\
$\begin{array}{c}\text { Above canopy } \\
\quad 35-41 \mathrm{~m}\end{array}$ & 1.2 & +9.2 & 0.81 & 14 & +73 & 0.56 \\
$\begin{array}{c}\text { In canopy } \\
12-19 \mathrm{~m}\end{array}$ & 0.94 & -19 & 0.62 & 16 & -137 & 0.70 \\
\hline
\end{tabular}

lated the chemical evolution of this cloud over a 1-hour period with the cloud chemistry model of Jacob [1986]. The cloud was assumed monodisperse (droplet radius $10 \mu \mathrm{m}$ ), with a constant liquid water content $\left(1 \mathrm{~g} \mathrm{~m}^{-3}\right)$ and a constant $p H$. The efficiency of $\mathrm{HCOOH}$ aqueous phase production is expected to be strongly $p \mathrm{H}$ dependent $[J a c o b, 1986]$. We find that at $p \mathrm{H} 5$ (the mean rainwater $p \mathrm{H}$ observed during ABLE 2B), the cloud is a net sink of $\mathrm{HCOOH}$ due to rapid aqueous phase oxidation of $\mathrm{HCOO}^{-}$by $\mathrm{OH}(\mathrm{aq})$. Total (gas phase) + (aqueous phase) concentrations of $\mathrm{HCOOH}$ decrease from $131 \mathrm{ppt}$ before cloud formation to $74 \mathrm{ppt} 1$ hour after cloud formation. At $p \mathrm{H} 4$ the cloud becomes a net source of $\mathrm{HCOOH}$, but after 1 hour of cloud the concentration has risen to only $154 \mathrm{ppt}$. We conclude that aqueous phase oxidation of $\mathrm{CH}_{2} \mathrm{O}$ cannot provide a significant source of $\mathrm{HCOOH}$ over the Amazon forest.

The missing sources of carboxylic acids in the model could possibly represent long-range transport of material exogenous to the Amazon Basin. In particular, the high concentrations observed in mission 16 were associated with recent influx of air from Africa (cf. section 3). Very high concentrations of carboxylic acids (i.e., ppb levels) have been observed in biomass-burning plumes advected from Africa to the tropical Atlantic (G. Helas et al., submitted, 1989). Ubiquitous pollution from sources outside the basin have been invoked to explain the observed concentrations of $\mathrm{NO}_{y}$ [Bakwin et al., this issue] and aerosol species.[Talbot et al., this issue] observed during ABLE $2 \mathrm{~B}$, and it seems reason-

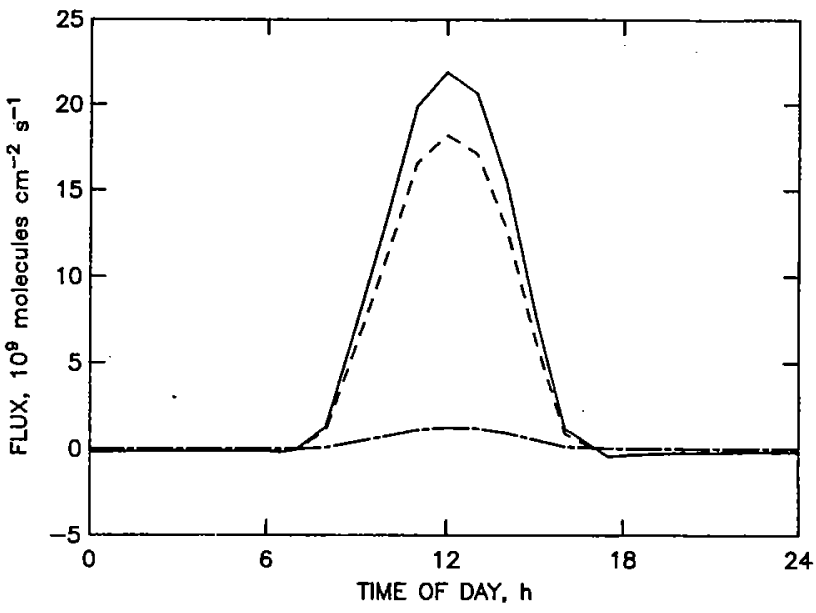

Fig. 9. Simulated vertical fluxes at canopy top, as a function of time of day, of $\mathrm{HCOOH}$ (solid line), $\mathrm{CH}_{3} \mathrm{COOH}$ (dashed line), and $\mathrm{CH}_{3} \mathrm{C}(\mathrm{O}) \mathrm{COOH}$ (dash-dot line). Positive values indicate upward fluxes. 

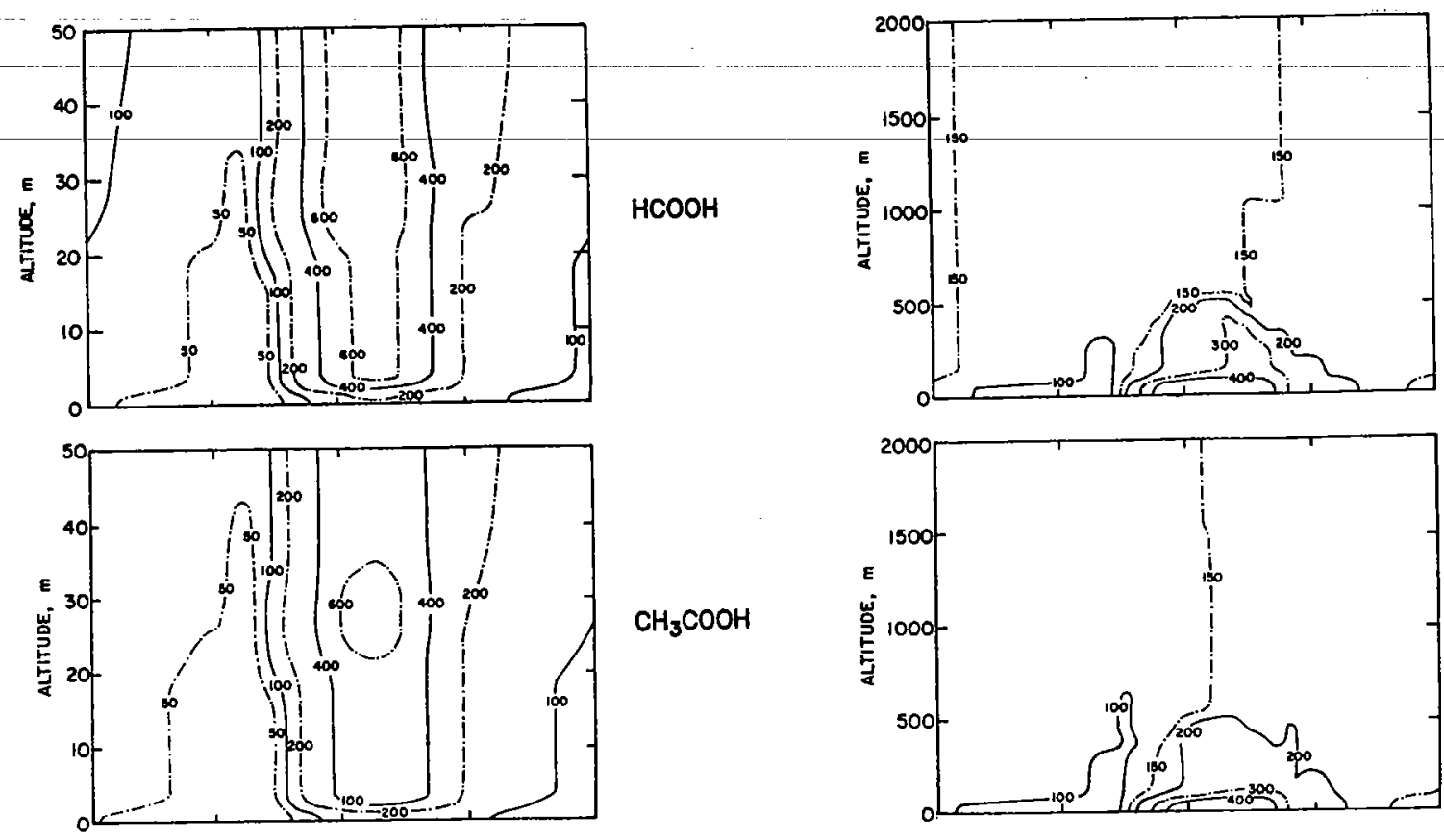

$\mathrm{HCOOH}$
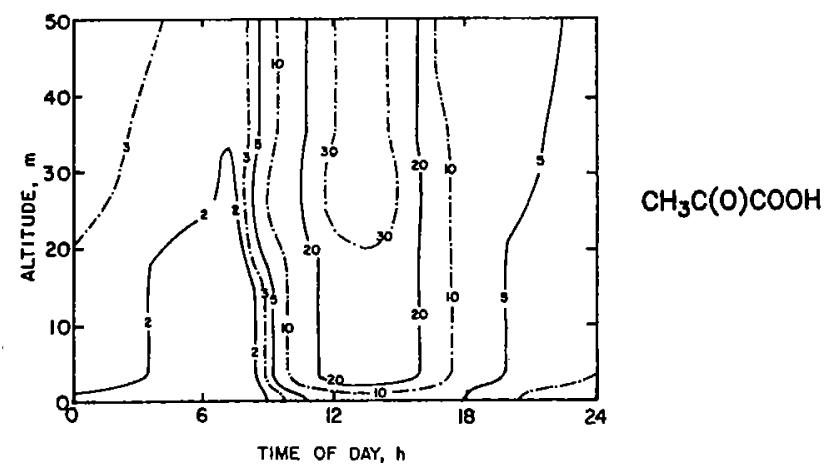

Fig. 10. Simulated concentrations (ppt) of HCOOH, $\mathrm{CH}_{3} \mathrm{COOH}$, and $\mathrm{CH}_{3} \mathrm{C}(\mathrm{O}) \mathrm{COOH}$ between 0 and $50 \mathrm{~m}$, as a function of time of day. The forest canopy extends from 0 to $30 \mathrm{~m}$.

able to postulate that such exogenous sources could have ubiquitously affected the carboxylic acid budgets as well.

It is possible that unknown chemical sources of carboxylic acids may be missing from the model. Our results indicate that peroxy-peroxy reactions involving $\mathrm{CH}_{3} \mathrm{CO}_{3}$ [Moortgat et al., 1989a,b] provide a substantial source of $\mathrm{CH}_{3} \mathrm{COOH}$ to the atmosphere (Table 4); other peroxy-peroxy reactions involving higher $\left(>C_{1}\right)$ peroxy or peroxyacyl radicals could provide additional sources of carboxylic acids, but no kinetic data are available. The atmosphere over the Amazon forest would be particularly conducive to peroxy-peroxy reactions because of the low concentration of NO, which hinders the consumption of peroxy radicals by NO. Hydroxy- $\mathrm{RO}_{2}$ radicals produced from the isoprene $+\mathrm{OH}$ reaction are expected to be abundant over the forest [Jacob and Wofsy, this issue], but the atmospheric reactivity of these radicals under low- $\mathrm{NO}_{x}$ conditions is essentially unknown.

Finally, microbial production of carboxylic acids in cloud droplets must be considered as a possible atmospheric source. Herlihy et al. [1987] observed high concentrations of bacteria in rain samples collected in Charlottesville, Virginia, and suggested that these bacteria were principally of vegetative origin. Production of carboxylic acids by vegeta-

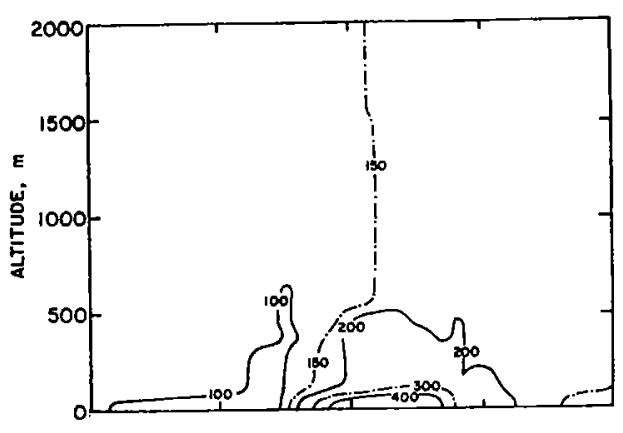

$\mathrm{CH}_{3} \mathrm{COOH}$

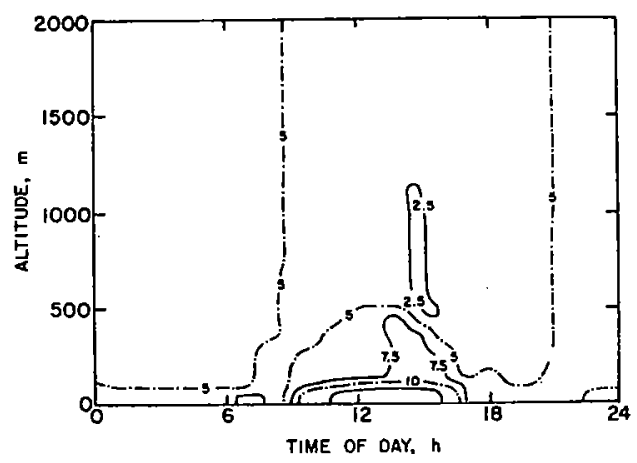

$\mathrm{CH}_{3} \mathrm{C}(\mathrm{O}) \mathrm{COOH}$

Fig. 11. Simulated concentrations (ppt) of $\mathrm{HCOOH}$, $\mathrm{CH}_{3} \mathrm{COOH}$, and $\mathrm{CH}_{3} \mathrm{C}(\mathrm{O}) \mathrm{COOH}$ in the boundary layer $(0-2000 \mathrm{~m})$, as a function of time of day.

TABLE 4. Simulated Budgets of Carboxylic Acids in the Boundary Layer $(30-2000 \mathrm{~m})$

\begin{tabular}{|c|c|c|c|}
\hline & Formic & Acetic & Pyruvic \\
\hline Concentration, ppt & 156 & 153 & 5.0 \\
\hline \multicolumn{4}{|l|}{$\begin{array}{l}\text { Sources and sinks, ppt } \\
\mathrm{d}^{-1}\end{array}$} \\
\hline Vegetative emissions & +88 & +73 & +5.5 \\
\hline Ventilation (at $2000 \mathrm{~m}$ ) & +4 & +7 & +3.8 \\
\hline Isoprene $+\mathrm{O}_{3}$ & +47 & & \\
\hline $\begin{array}{l}\text { Methylvinylketone + } \\
\mathrm{O}_{3}\end{array}$ & +10 & & +9.9 \\
\hline Methacrolein $+\mathrm{O}_{3}$ & +1 & & \\
\hline $\mathrm{CH}_{3} \mathrm{CO}_{3}+\mathrm{HO}_{2}$ & & +35 & \\
\hline $\mathrm{CH}_{3} \mathrm{CO}_{3}+\mathrm{CH}_{3} \mathrm{O}_{2}$ & & +39 & \\
\hline Wet deposition & -156 & -153 & -5.0 \\
\hline $\mathrm{HCOOH}+\mathrm{OH}$ & -1 & & \\
\hline $\mathrm{CH}_{3} \mathrm{C}(\mathrm{O}) \mathrm{COOH}+h \nu$ & & & -13.5 \\
\hline Accumulation, ppt $\mathrm{d}^{-1}$ & -7 & +1 & +0.7 \\
\hline
\end{tabular}

Values are 24-hour mean model values averaged over the boundary layer air column $(30-2000 \mathrm{~m})$. 
tive microbes has been extensively documented [e.g., Schmidt, 1986; Rozycki and Strzelczyk, 1986], but the possibility of such production in atmospheric cloud droplets remains a matter of speculation. Bacterial activity in cloud droplets could actually provide a sink for carboxylic acids instead of a source; in particular, bacteria observed in rain samples were found to utilize efficiently $\mathrm{HCOO}^{-}$and $\mathrm{CH}_{3} \mathrm{COO}^{-}$, although this utilization did not begin until after an incubation period of a few days [Herlihy et al., 1987].

The atmospheric concentrations of $\mathrm{HCOOH}$ and $\mathrm{CH}_{3} \mathrm{COOH}$ observed in the wet season were a factor of 3-5 lower than those observed in the dry season ABLE 2A experiment [Andreae et al., 1988a]. This difference can be explained largely by the longer atmospheric lifetimes of carboxylic acids against wet deposition in the dry season. Rainfall at Manaus varies by a factor of 4 between the dry and wet seasons [Kousky and Kagano, 1981], and this factor could account for the observed variations in $\mathrm{HCOOH}$ and $\mathrm{CH}_{3} \mathrm{COOH}$ concentrations. The ABLE $2 \mathrm{~A}$ model calculations of Jacob and Wofsy [1988a] suggest that $\mathrm{HCOOH}$ production from ozonolysis of olefins could have contributed only $15-50 \%$ of the $\mathrm{HCOOH}$ concentrations observed in the dry season; we find in the wet season that this contribution is even less because $\mathrm{O}_{3}$ concentrations are about a factor of 2 lower [Browell et al., this issue]. Sources of $\mathrm{CH}_{3} \mathrm{COOH}$ were not included in the model of Jacob and Wofsy [1988a], but more recent model simulations of the ABLE $2 \mathrm{~A}$ data by Madronich and Calvert [1990] indicate that peroxy-peroxy reactions involving $\mathrm{CH}_{3} \mathrm{CO}_{3}$ could have been important contributors to the observed $\mathrm{CH}_{3} \mathrm{COOH}$ concentrations. As in the wet season, it seems logical to speculate that other peroxy-peroxy radical reactions (involving $>C_{I}$ radicals) may have been important sources of carboxylic acids in the dry season. Biomass burning, which is widespread in Amazonia and the savannah areas to the south during the dry season [Andreae et al., 1988b] could have supplied an important additional source [Talbot et al., 1988].

\section{Conclusions}

In this paper we have presented a likely scenario of the gas phase carboxylic acid regime during the April-May segment of the 1987 wet season in central Amazonia. We utilized data obtained within the forest canopy, the PBL, and free troposphere, in combination with a photochemical model to evaluate potential biogenic and atmospheric sources and sinks of $\mathrm{HCOOH}, \mathrm{CH}_{3} \mathrm{COOH}$, and $\mathrm{CH}_{3} \mathrm{C}(\mathrm{O}) \mathrm{COOH}$. The distribution of $\mathrm{HCOOH}$ in the boundary layer from the Atlantic Ocean westward to central Amazonia shows a strong continental source for this species. Despite frequent precipitation over central Amazonia, $\mathrm{HCOOH}$ was enhanced by a factor of 2.5 in the boundary layer compared with the free troposphere. Concentrations of carboxylate ions in the atmospheric aerosol were usually below our detection limit of 5-10 ppt.

The diurnal cycles of $\mathrm{HCOOH}, \mathrm{CH}_{3} \mathrm{COOH}$, and $\mathrm{CH}_{3} \mathrm{C}(\mathrm{O}) \mathrm{COOH}$ just above the forest canopy showed a rapid increase in concentration from early morning to midafternoon, followed by a decrease beginning around $1500 \mathrm{LT}$. This behavior suggests daytime biogenic and photochemical production followed by deposition to vegetation at night.

We used a one-dimensional photochemical model to estimate the contributions from various sources to the observed concentrations of carboxylic acids. Direct emissions from vegetation can account for most of the observed concentrations within the canopy and just above it. Concentrations in the boundary layer are much higher than would be expected from direct emissions, suggesting an important source from secondary production. However, we find that the atmospheric reactions considered in the model (decomposition of isoprene, $\mathrm{CH}_{3} \mathrm{CO}_{3}+$ peroxy, aqueous phase oxidation of $\mathrm{CH}_{2} \mathrm{O}$ ) are too slow to account for the observed concentrations. Unknown atmospheric reactions (possibly interactions between organic peroxy radicals) appear to dominate the budget of carboxylic acids over Amazonia.

Acknowledgments. We thank the Government of Brazil for permission to conduct research in Amazonia and acknowledge the collaboration of the Brazilian science team under the leadership of $J$. R. B. Coelho. Logistical support at Ducke Forest Reserve was provided by the Instituto Nacional de Pesquisas da Amazonia (INPA). The cooperation of the flight crew of the NASA Electra research aircraft and the staff of the NASA Wallops Flight Center is gratefully acknowledged. This research was supported by the NASA Tropospheric Chemistry Program. D.J.J. acknowledges support from NSF (grants NSF-ATM 8413153 and NSF-ATM 8858074).

\section{REFERENCES}

Andreae, M. O., R. W. Talbot, and S. M. Li, Atmospheric measurements of pyruvic and formic acid, J. Geophys. Res., 92, 6635-6641, 1987.

Andreae, M. O., R. W. Talbot, T. W. Andreae, and R. C. Harriss, Formic and acetic acid over the central Amazon region, Brazil, 1, Dry season, J. Geophys. Res., 93, 1616-1624, 1988a.

Andreae, M. O., et al., Biomass-burning emissions and associated haze layers over Amazonia, J. Geophys. Res., 93, 1509-1527, $1988 b$.

Andreae, M. O., R. W. Talbot, H. Berresheim, and K. M. Beecher, Precipitation chemistry in central Amazonia, J. Geophys. Res., this issue $(a)$.

Andreae, M. O., H. Berresheim, H. Bingemer, D. J. Jacob, B. L. Lewis, S. M. Li, and R. W. Talbot, The atmospheric sulfur cycle over the Amazon Basin, J. Geophys. Res., this issue (b).

Atkinson, R., and A. L. Lloyd, Evaluation of kinetic and mechanistic data for modeling of photochemical smog, J. Phys. Chem. Ref. Data, 13, 315-444, 1984.

Bakwin, P. S., S. C. Wofsy, and S.-M. Fan, Measurements of reactive nitrogen oxides $\left(\mathrm{NO}_{\mathrm{y}}\right)$ within and above a tropical forest canopy in the wet season, J. Geophys. Res., this issue.

Browell, E. V., G. L. Gregory, R. C. Harriss, and V. W. J. H. Kirchhoff, Ozone and aerosol distributions over the Amazon Basin during the wet season, J. Geophys. Res., this issue.

Chameides, W. L., The photochemistry of a remote marine stratiform cloud, J. Geophys. Res., 89, 4739-4755, 1984.

Chameides, W. L., and D. D. Davis, Aqueous-phase source of formic acid in clouds, Nature, 304, 427-429, 1983.

Fan, S.-M, S. C. Wofsy, P. S. Bakwin, and D. J. Jacob, Atmosphere-biosphere exchange of $\mathrm{CO}_{2}$ and $\mathrm{O}_{3}$ in the central Amazon forest, $J$. Geophys. Res., this issue.

Galloway, J. N., G. E. Likens, W. C. Keene, and J. M. Miller, The composition of precipitation in remote areas of the world, $J$. Geophys. Res., 87, 8771-8786, 1982.

Graedel, T. E., and T. Eisner, Atmospheric formic acid from formicine ants: A preliminary assessment, Tellus, 40B, 335-339, 1988.

Harriss, R. C., et al., The Amazon Boundary Layer Experiment: Wet season 1987, J. Geophys. Res., this issue.

Herlihy, L. J., J. N. Galloway, and A. L. Mills, Bacterial utilization of formic and acetic acid in rainwater, Atmos. Environ., 21, 2397-2402, 1987.

Jacob, D. J., Chemistry of $\mathrm{OH}$ in remote clouds and its role in the production of formic acid and peroxymonosulfate, $J$. Geophys. Res., 91, 9807-9826, 1986.

Jacob, D. J., and S. C. Wofsy, Photochemistry of biogenic emis- 
sions over the Amazon forest, J. Geophys. Res., 93, 1477-1486, $1988 a$.

Jacob, D. J., and S. C. Wofsy, Photochemical production of carboxylic acids in a remote continental atmosphere, in Acid Deposition Processes at High Elevation Sites, edited by M. H. Unsworth, pp. 73-92, D. Reidel, Hingham, Mass., $1988 b$.

Jacob, D. J., and S. C. Wofsy, Budgets of reactive nitrogen, hydrocarbons, and ozone over the Amazon forest during the wet season, J. Geophys. Res., this issue.

Keene, W. C., and J. N. Galloway, Considerations regarding sources for formic and acetic acids in the troposphere, J. Geophys. Res., 91, 14,466-14,474, 1986.

Keene, W. C., et al., An intercomparison of measurement systems for vapor and particulate phase concentrations of formic and acetic acids, J. Geophys. Res., 94, 6457-6471, 1989.

Kousky, V. E., and M. T. Kagano, A climatological study of the tropospheric circulation over the Amazon region, Acta Amazonica, $11,743-758,1981$.

Madronich, S., and J. G. Calvert, Permutation reactions of organic peroxy radicals in the troposphere, J. Geophys. Res., 95, 5697$5715,1990$.

Meyers, T. P., and D. D. Baldocchi, A comparison of models for deriving dry deposition fluxes of $\mathrm{O}_{3}$ and $\mathrm{SO}_{2}$ to a forest canopy, Tellus, 40B, 270-284, 1988.

Miller, R. L., and J. S. Kahn, Statistical Analysis in the Geophysical Sciences, John Wiley, New York, 1962.

Moortgat, G. K., B. Veyret, and R. Lesclaux, Absorption spectrum and kinetics of the acetylperoxy radical, J. Phys. Chem., 93, 2362-2368, 1989a.

Moortgat, G. K., B. Veyret, and R. Lesclaux, Kinetics of the reaction of $\mathrm{HO}_{2}$ with $\mathrm{CH}_{3} \mathrm{C}(\mathrm{O}) \mathrm{O}_{2}$ in the temperature range 253-368 K, Chem. Phys. Lett., 160, 443-447, 1989 b.

Rasmussen, R. A., and M. A. K. Khalil, Isoprene over the Amazon Basin, J. Geophys. Res., 93 1417-1421, 1988.

Roberts, J., O. M. R. Cabral, and L. F. De Aguiar, Stomatal and boundary-layer conductances measured in a-Terra Firme rain forest, Manaus, Amazonas, Brazil, J. Appl. Ecol., in press, 1989.

Rozycki, H., and E. Strzelczyk, Organic acids production by Streptomyces spp. isolated from soil, rhizosphere and mycorrhizosphere of pine (Pinus sylvestris L.), Plant Soil, 96, 337-345, 1986.

Scala, J. R., et al., Cloud draft structure and trace gas transport, $J$. Geophys. Res., this issue.

Schmidt, $O$., Investigations on the influence of wood-inhabiting bacteria on the $p \mathrm{H}$-value in trees, Eur. J. For. Pathol., 16, 181-189, 1986.

Talbot, R. W., K. M. Beecher, R. C. Harriss, and W. R. Cofer, Atmospheric geochemistry of formic and acetic acids at a midlatitude temperate site, J. Geophys. Res., 93, 1638-1652, 1988.

Talbot, R. W., M. O. Andreae, H. Berresheim, P. Artaxo, M. Garstang, R. C. Harriss, K. M. Beecher, and S. M. Li, Aerosol chemistry during the wet season in central Amazonia: The influence of long-range transport, J. Geophys. Res., this issue.

M. O. Andreae, Max-Planck-Institute for Chemistry, Postfach 3060, D-6500 Mainz, Federal Republic of Germany.

K. M. Beecher, Atmospheric Sciences Division, NASA Langley Research Center, Hampton, VA 23665.

H. Berresheim, School of Geophysical Sciences, Georgia Institute of Technology, Atlanta, GA 30332.

D. J. Jacob, Earth and Planetary Sciences, Division of Applied Science, Harvard University, Cambridge, MA 02138.

R. W. Talbot, Institute for the Study of Earth, Oceans and Space, University of New Hampshire, Durham, NH 03824.

(Received September 5, 1989; revised January 8, 1990; accepted January 8,1990 .) 